\title{
Akibat Hukum Terdegradasinya Akta Notaris yang Tidak Memenuhi Syarat Pembuatan Akta Autentik
}

\author{
Agus Toni Purnayasa ${ }^{1}$ \\ 1Program Studi Magister (S2) Kenotariatan Fakultas Hukum Universitas Udayana, Bali- \\ Indonesia, E-mail: agustonipurnayasa@ymail.com
}

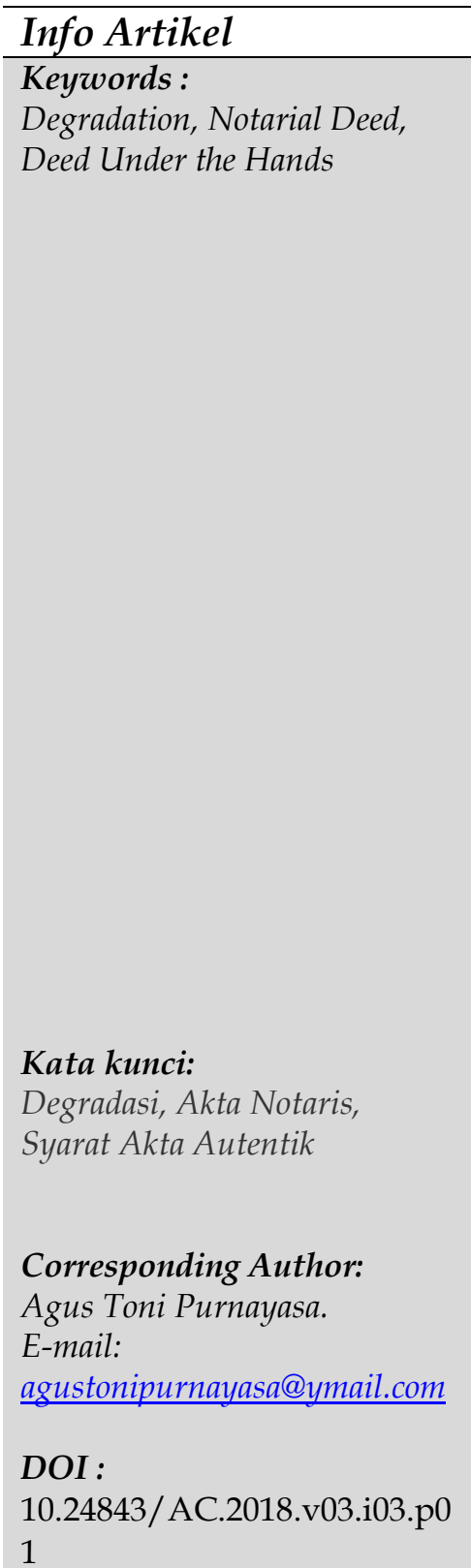

Info Artikel

Keywords :

Degradation, Notarial Deed,

Deed Under the Hands

Degradasi, Akta Notaris,

Syarat Akta Autentik

Corresponding Author:

Agus Toni Purnayasa.

E-mail:

agustonipurnayasa@ymail.com

DOI

\begin{abstract}
As a Public Officer with the intention to make an authentic deed, the Notary often acts inadvertently and inadvertently, it can certainly lead to legal problems. Authentic deeds made by Notary also do not rule out can be a deed under the hands. Notarial deeds as authentic deeds that have perfect evidentiary power in civil law disputes may, in fact, degenerate from the perfect evidentiary power to such a deed under the hand, and may be legally defamatory resulting in the disregard or invalidity of the Notary's deed. Based on the background of the problem can be formulated as follows, how a deed can be said or categorized as an authentic deed and how authentic deeds can experience the degradation of the power of proof into the deed under the hands. This research is normative law research. The results of the study conclude that the Notary Act can be an authentic deed if it meets the formalities that are already determined based on the rules contained in the provisions of Article 1868 Civil Code and jo UUJN. Based on the provisions of Article 1868 Civil Code must be fulfilled the requirements of authentic deed and authentic deed must be made in accordance with the format specified in accordance with the provisions of Article 38 UUJN and Deed can be degraded into deed under the hand if violating the provisions of Article 1868 Civil Code jo UUJN.
\end{abstract}

\footnotetext{
Abstrak

Sebagai Pejabat Umum yang berwenag untuk membuat akta autentik, Notaris sering kali bertindak tidak hati-hati dan tidak seksama, sehingga apa yang diisyaratkan oleh undang-undang yaitu tentang syarat pembuatan akta autentik kadang kala tidak diperhatikan oleh pejabat umum yang berwenang untuk membuat Akta Autentik khusunya dalam hal ini adala Notaris, hal tersebut tentunya dapat menimbulkan permasalahan hukum. Akta autentik yang dibuat oleh Notaris juga tidak menutup kemungkinan dapat menjadi akta di bawah tangan. Akta Notaris sebagai akta autentik yang memiliki kekuatan pembuktian yang sempurna dalam sengketa hukum perdata, ternyata dapat mengalami penurunan status (degradasi) dari kekuatan pembuktian yang sempurna menjadi seperti akta dibawah tangan, dan dapat cacat hukum yang menyebabkan kebatalan atau ketidakabsahan akta Notaris tersebut. Berdasarkan latar belakang permasalahan tersebut maka dapat dirumuskan
} 
permasalah sebagai berikut, Apa Akibat hukum dari suatu akta autentik yang terdegradasi Bagaimanakah akta autentik tersebut dapat mengalami degradasi kekuatan pembuktian menjadi akta di bawah tangan. Penelitian ini merupakan penelitian hukum normatif. Hasil studi menyimpulkan bahwa akta Notaris dapat menjadi akta yang autentik apabila memenuhi formalitasformalitas yang memang sudah ditentukan berdasarkan aturan yang ada dalam ketentuan Pasal 1868 KUH Perdata dan jo UUJN. Berdasarkan ketentuan Pasal 1868 KUH Perdata haruslah dipenuhi syarat akta autentik serta akta otentik haruslah dibuat sesuai dengan format yang sudah ditentukan berdasarkan ketentuan Pasal 38 UUJN dan Akta Notaris dapat terdegradasi menjadi akta di bawah tangan apabila melanggar ketentuan Pasal 1868 KUH Perdata jo UUJN.

\section{Pendahuluan}

Perkembangan masyarakat pada saat ini sangatlah pesat, hal tersebut tentunya membuat kebutuhan masyarakat semakin meningkat. Kondisi perekonomian yang semakin berkembang tersebut tentunya menyebabkan masyarakat luas tertarik untuk melakukan suatu usaha untuk mencukupi kebutuhan sehari-hari. Tidak jarang dalam kegiatan perekonomian yang dilakukan oleh masyarakat tersebut membutuhkan suatu modal yang besar, hal tersebut tentunya membutuhkan suatu perjanjian yang dibuat oleh masyarakat untuk dapat menjalankan usahanya, dan dalam membuat suatu perjanjian maka tidak sekedar perjanjian di bawah tangan saja, akan tetapi untuk membuat suatu perjanjian yang autentik yang dibuat oleh dan di hadapan Notaris. Alasan untuk membuat perjanjian di hadapan Notaris ini bukan karena tidak adanya kepercayaan antara satu sama lain, akan tetapi agar lebih memberikan suatu perlindungan hukum atas kepentingan para pihak apabila nantinya terjadi suatu permasalahan di kemudian hari terkait dengan terlaksananya perjanjian tersebut.

Dewasa ini lembaga Notaris semakin dikenal oleh masyarakat dan sangat diperlukan untuk membuat suatu alat bukti yang tertulis dan tentunya yang bersifat autentik mengenai suatu perbuatan hukum tertentu yang diperbuat oleh anggota masyarakat. Kebutuhan atas lembaga kenotariatan dalam praktek hukum kehidupan bermasyarakat tersebut tidaklah mungkin dapat dilepaskan, hal tersebut berguna untuk dapat meningkatnya laju perekonomian dan kesadaran masyarakat akan hukum, kekuatan akta autentik yang dibuat oleh Notaris tentunya memiliki kekuatan serta kepastian hukum yang sangat kuat dan mengingat, akta autentik merupakan alat bukti yang sempurna, maka tidak jarang berbagai peraturan perundangan mewajibkan suatu perbuatan hukum tertentu dibuat dalam bentuk akta autentik. ${ }^{1}$

\footnotetext{
${ }^{1}$ Prayojana, D. A., Murni, R. R., \& Dharmawan, N. K. S. (2018). Pelaksanaan Penyelesaian Pelanggaran Kode Etik Notaris Tentang Pemasangan Papan Nama Notaris Di Kota Denpasar. Acta Comitas, h, 213
} 
Perjanjian yang dibuat oleh para pihak di hadapan Notaris tersebut dituangkan ke dalam suatu Akta Notaris. Akta tersebut merupakan suatu akta autentik yang memiliki kekuatan yang sempurna dan merupakan suatu alat bukti yang sah tanpa diperlukan lagi alat bukti lain dalam suatu sengketa hukum perdata. Berdasarkan ketentuan Pasal 15 Undang-Undang Republik Indonesia Nomor 2 Tahun 2014 Tentang Perubahan Atas Undang-Undang Nomor 30 Tahun 2004 Tentang Jabatan Notaris, Lembaran Negara Republik Indonesia Tahun 2014 Nomor 293, Tambahan Lembaran Negara Republik Indonesia Nomor 5602 (selanjutnya disebut UUJN), menentukan bahwa:

Notaris berwenang membuat Akta autentik mengenai semua perbuatan, perjanjian, dan penetapan yang diharuskan oleh peraturan perundangundangan dan/atau yang dikehendaki oleh yang berkepentingan untuk dinyatakan dalam Akta autentik, menjamin kepastian tanggal pembuatan Akta, menyimpan Akta, memberikan grosse, salinan dan kutipan Akta, semuanya itu sepanjang pembuatan Akta itu tidak juga ditugaskan atau dikecualikan kepada pejabat lain atau orang lain yang ditetapkan oleh undang-undang.

Selanjutnya R. Soegondo memberikan pendapatnya mengenai pengertian akta autentik, ia menyatakan bahwa: "Akta autentik merupakan suatu akta yang dibuat berdasarkan bentuk yang sudah ditentukan menurut hukum, oleh atau di hadapakan pejabat-pejabat umum yang meang memiliki kewenagan untuk membuat akta tersebut ditempat dimana akta autentik tersebut dibuat". ${ }^{2}$

Akta autentik memiliki 2 (dua) fungsi utama, antara lain yaitu, sebgai fungsi formil (formalitas causa) dan berfungsi sebagai alat bukti (probationis causa). Fungsi formil (formalitas causa) dapat diartikan bahwa untuk membuat suatu perbuatan dinyatakan lengkap dan sempurnanya (bukan untuk sahnya) suatu perbuatan hukum haruslah dibuat dalam bentuk akta autentik. Berfungsi sebagai alat bukti (probationis causa) dapat diartikan bahwa akta autentik tersebut sengaja dibuat sebagai pembuktian dikemudian hari, akta autentik tersebut dibuat tertulis mengenai suatu perjanjian. ${ }^{3}$ Akta autentik merupakan satu bukti tertulis yang memiliki kekuatan pembuktian yang sangat sempurna sebagai alat bukti. Akta autentik diperlukan bagi mereka yang membutuhkan suatu alat pembuktian untuk suatu kepentingan pribadi maupun untuk kepentingan suatu usaha, seperti akta pendirian Perseroan Terbatas, Firma, perkumpulan perdata dan lain-lainnya. ${ }^{4}$

Berdasarkan ketentuan Pasal 1868 Kitab Undang-Undang Hukum Perdata (selanjutnya disebut KUH Perdata), menentukan bahwa: “akta autentik adalah akta yang dibuat

2 Krisno, A. D. J., Dharmawan, N. K. S., \& Darmadi, A. S. W. (2015). Akibat Hukum Yang Ditimbulkan Dari Wanprestasi Dalam Perjanjian Autentik Sewa-Menyewa Tanah.

${ }^{3}$ Sudikno Mertokusumo. (1999). Mengenal Hukum Suatu Pengantar. Yogyakarta: Liberty, h. 121

${ }^{4}$ R. Soegondo Notodisoerjo. (1993). Hukum Notariat di Indonesia (Suatu Penjelasan). Jakarta: Raja Grafindo Persada, h. 9 
dalam bentuk yang ditentukan oleh undang-undang, oleh atau di hadapan pejabat umum yang berwenang untuk itu di tempat akta itu dibuat". Akta autentik yang dibuat oleh atau di hadapan Pejabat Umum juga tidak menutup kemungkinan dapat menjadi akta di bawah tangan, hal tersebut dapat terjadi bilamana pejabat tersebut tidak berwenang untuk membuat akta itu dan jika terdapat cacat dalam bentuk akta autentik tersebut, sebagaimana disebut dalam Pasal 1868 KUH Perdata. Akta di bawah tangan mempunyai kelemahan yang sangat nyata yaitu dalam hal pembuktian akta di bawah tangan harus di dampingi dengan alat pembuktian lain karena bukan merupakan alat bukti yang sempurna. ${ }^{5}$ Berdasarkan pada ketentuan aturan peraturan perundang-undangan di Indonesia, maka Pejabat Umum yang setidaknya dikenal yaitu Notaris dan Pejabat Pembuat Akta Tanah (PPAT). Berdasarkan ketentuan Pasal 1868 KUH Perdata tersebut mana setidaknya harus dipahami mengenai bentuk akta otentik haruslah memenuhi unsur sebagai berikut ini:

1) Bentuk akta yang memang sudah ditentukan berdasarkan aturan undangundang dari suatu akta agar dianggap sebagai akta autentik;

2) Dibuat oleh atau di hadapan pejabat umum yang berwenang;

3) Di tempat akta itu dibuat.

Bentuk dan sifat akta Notaris sudah ditentukan berdasarkan undang-undang. Mengacu pada ketentuan Pasal 1868 KUH Perdata maka untuk menjadi akta autentik maka bentuknya harus sesuai sebagaimana ditentukan oleh undang-undang. Mengenai bentuk akta Notaris sudah ditentukan berdasarkan ketentuan Pasal 38 ayat (1) UUJN. Disamping telah memenuhi ketentuan Pasal 38 UUJN tersebut suatu akta Notaris dapat dikatakan memenuhi syarat sebagai akta autentik apabila akta Notaris tersebut telah sesuai dengan prosedur atau tata cara yang telah ditentukan, yaitu memenuhi ketentuan yang ada dalam Pasal 39 UUJN sampai dengan Pasal 53 UUJN. Mengenai bentuk akta autentik yang dibuat oleh Notaris maka terdapat 2 (dua) macam, antara lain yaitu:

1. Akta yang dibuat oleh (door) Notaris atau yang dapat dinamakan sebagai akta relaas atau dinamakan sebagi akta pejabat (ambtelijke akten)

Akta relaas yaitu suatu akta yang dibuat oleh Notaris yang memuat uraian dari Notaris mengenai suatu tindakan yang dilakukan atas tentang suatu keadaan yang dilihat dan disaksikan Notaris. Contohnya yaitu risalah rapat dan akta berita acara perseroan terbatas, akta pencatatan budel dan sebagainya.

2. Akta yang dibuat di hadapan (ten overstaan) Notaris atau yang dapat dinamakan sebagai akta partij (partij akten).

Akta partij yaitu suatu akta yang dibuat oleh dan di hadapan Notaris yang memuat uraian dari apa yang diterangkan atau diceritakan oleh para penghadap yang menghadap kepada Notaris. Contohnya yaitu perjanjian kredit, perjanjian hak tanggungan dan sebagainya.

Akta selain bersifat autentik dapat juga bersifat sebagai akta di bawah tangan saja. Pasal $1874 \mathrm{KUH}$ Perdata menentukan bahwa: "yang dianggap sebagai tulisan di bawah tangan adalah akta yang ditandatangani di bawah tangan, surat, daftar, surat

\footnotetext{
${ }^{5}$ Nitasari, K. R. (2018). Akibat Hukum Dari Perjanjian Kredit Bank Yang Tidak Dilegalisasi Oleh Notaris.
} 
urusan rumah tangga dan tulisan-tulisan yang lain yang dibuat tanpa perantaraan seorang pejabat umum". Jadi akta di bawah tangan hanya dapat diterima sebagai permulaan bukti tertulis, namun menurut pasal tersebut tidak dijelaskan apa yang dimaksud dengan bukti tertulis. Dalam ketentuan Pasal 1902 KUH Perdata menentukan mengenai syarat-syarat bilamana terdapat bukti tertulis yaitu harus ada akta, akta autentik tersebut wajib dibuat oleh atau dari orang yang diwakilinya dan akta itu harus memungkinkan kebenaran peristiwa yang bersangkutan. Jadi suatu akta di bawah tangan dapat menjadi suatu alat bukti yang sempurna dan lengkap dari permulaan bukti tertulis maka haruslah dilengkapi dengan alat bukti lainnya. Berdasarkan penjelaan tersebut maka disimpulkan bahwa akta di bawah tangan merupakan suatu alat bukti tertulis (begin van schriftelijk bewijs). Jika ditinjau dari segi hukum pembuktian maka agar suatu tulisan dapat bernilai sebagai akta di bawah tangan diperlukan syarat yaitu, surat atau tulisan itu haruslah ditandatangani, isi yang diterangkan di dalamnya menyangkut mengenai suatu hubungan hukum (rechts betrekking) maupun suatu perbuatan hukum (rechtshandeling) yang memang sengaja dibuat untuk dapat dijadikan suatu bukti dari suatu perbuatan hukum tertentu.

Perbedaan pokok antara akta autentik dengan akta di bawah tangan ialah mengenai tata cara pembuatan atau terjadinya akta tersebut. Akta yang dibuat di bawah tangan ialah suatu tulisan yang memang sengaja dijadikan alat bukti tentang suatu peristiwa ataupun suatu kejadian yang nantinya akta tersebut wajib untuk ditandatangani, oleh karena itu adanya unsur yang sangat penting yaitu adanya unsur kesengajaan untuk membuat suatu alat bukti yang tertulis dan dilakukannya penandatanganan pada akta autentik tersebut. Keharusan mengenai adanya tanda tangan bertujuan untuk dapat memberi ciri atau untuk menginvidualisir suatu akta. Sebagai suatu alat bukti dalam suatu persidangan di pengadilan, maka akta yang di bawah tangan tidaklah memiliki suatu kekuatan pembuktian yang sempurna dikarenakan mengenai kebenarannya terletak pada tanda tangan para pihak yang jika hal tersebut diakui maka menjadi suatu alat bukti yang sempurna seperti halnya akta autentik. Akta autentik merupakan suatu alat pembuktian yang sempurna bagi semua pihak yang terkait dengan akta otentik tersebut. Akta autentik merupakan suatu alat bukti yang sifatnya mengikat, yang berarti kebenaran dari apa yang tertulis dalam isi akta tersebut harus diakui oleh semua pihak, yaitu akta tersebut haruslah dapat dianggap benar selama kebenarannya itu tidak dapat dibuktikan sebaliknya. Sedangkan akta di bawah tangan dapat menjadi alat pembuktian yang sempurna terhadap orang yang menandatangani.

Sebagai Pejabat umum yang berwenang untuk membuat suatu akta autentik, maka Notaris sering kali bertindak tidak hati-hati dan tidak seksama dalam menjalankan tugas dan jabatannya, hal tersebut tentunya dapat menimbulkan permasalahan hukum, baik dalam ranah hukum perdata maupun pidana, hal tersebut dapat disebabkan karena penghadap yang membuat akta autentik memberikan dokumn palsu ataupun memberikan keterangan palsu kepada Notaris sehingga hal tersebuut menimbulkan permasalahan hukum terhadap akta autentik yang dibuatnya. ${ }^{6}$ Notaris sebagai manusia biasa dalam menjalankan tugas dan jabatannya dapat melakukan

6 https://ojs.unud.ac.id/index.php/ActaComitas/article/view/39328/23810, Jurnal Acta Comitas, Ida Bagus Parmaningrat Manuaba, 2017, Prinsip Kehati-hatian Notaris Dalam Membuat Akta Autentik, Mahasiswa Magister Kenotariatan Fakultas Hukum Udayana, Bali, (diakses 11 Juni 2018) 
suatu kesalahan maupun pelanggaran. Notaris yang terbukti melakukan pelanggaran terhadap kewajiban dan larangan Notaris sebagaimana diatur dalam ketentuan Pasal 16 dan 17 UUJN dapat dikenakan sanksi, baik berupa sanksi administratif, sanksi kode etik, sanksi perdata dan sanksi pidana. ${ }^{7}$

Akta Notaris sebagai akta autentik yang memiliki kekuatan pembuktian yang sempurna dalam sengketa hukum perdata, ternyata dapat mengalami penurunan status (degradasi) dari kekuatan bukti lengkap dan sempurna menjadi seperti akta dibawah tangan, dan dapat cacat hukum yang menyebabkan kebatalan atau ketidakabsahan akta Notaris tersebut. Bertolak dari uraian pada latar belakang yang sudah jabarkan di atas, maka dapat dirumuskan 2 (dua) permasalahan, yaitu sebagai berikut:

1. Apa Akibat hukum dari suatu akta autentik yang terdegradasi ?

2. Bagaimanakah akta autentik tersebut dapat mengalami degradasi kekuatan pembuktian menjadi akta di bawah tangan?

Teori kepastian hukum merupakan salah satu teori terpenting dalam negara hukum. Tanpa adanya kepastian dalam hukum maka akibatnya hukum tersebut pastinya akan kehilangan nilainya dan tidak dapat dijadikan suatu pedoman dalam kehidupan bermasyarakat. Menurut Gustav Radbruch sebagaimana dikutip oleh Notohamidjojo dalam bukunya menyatakan bahwa: "hukum memiliki tujuan yang berorientasi pada hal-hal berikut, yaitu kepastian hukum, keadilan, daya guna atau kemanfaatan". ${ }^{8}$ Teori Kepastian Hukum dipergunakan untuk membahas mengenai rumusan permasalahan pertama mengenai suatu akta dapat dikatakan atau dikategorikan sebagai akta autentik.

Teori penafsiran dicetuskan oleh J. A Pontier yang menyatakan bahwa: "agar dapat mengatur masyarakat hukum harus ditafsirkan". Penafsiran yang dilakukan dalam penelitian ini menggunakan metode interpretasi secara gramatikal dan interpretasi secara sistematis. ${ }^{9}$ Teori Penafsiran Hukum disini dipergunakan untuk membahas mengenai rumusan permasalahan kedua mengenai akta autentik tersebut dapat mengalami degradasi menjdi kekuatan pembuktian menjadi akta di bawah tangan.

Bertujuan untuk dapat mengembangkan ilmu hukum, khususnya dibidang hukum kenotariatan dan untuk mengkaji mengenai tinjauan hukum terhadap degradasi akta Notaris menjadi akta di bawah tangan yang disebabkan pelanggaran peraturan perundang-undangan dan tidak dipenuhinya syarat akta autentik oleh Notaris. Sementara itu sesuai dengan rumusan permasalahan yang dibahas dalam penelitian ini, maka adapun tujuan khusus dari penelitian ini yaitu untuk dapat mengetahui serta untuk menganalisis mengenai suatu akta dapat dikatakan atau dikategorikan sebagai akta autentik dan untuk memahami dan menganalisis mengenaii akta autentik tersebut dapat mengalami degradasi kekuatan pembuktian menjadi akta di bawah tangan.

\footnotetext{
7 Setiabudhi, I. K. R., \& Swardhana, G. M. (2017). Sanksi Hukum Terhadap Notaris Yang Melanggar Kewajiban Dan Larangan Undang-Undang Jabatan Notaris. Acta Comitas, h. 110

${ }^{8}$ Notohamidjojo. (2011). Soal-Soal Pokok Filsafat Hukum. Salatiga: PT. Griya Media, h. 33

9 J.A. Pontier. (2008). Penemuan Hukum, diterjemahkan. Bandung: Jendela Mas Pustaka, h. 94
} 


\section{Metode Penelitian}

Penelitian ini mempergunakan penelitian hukum normatif, yaitu penelitian hukum yang meneliti dan mengkaji norma hukum yang terdapat di dalam ketentuan aturan peraturan perundang-undangan. ${ }^{10}$ Penelitian ini merupakan jenis penelitian hukum normatif karena penelitian ini beranjak dari adanya kekaburan norma dalam UndangUndang Jabatan Notaris. Adanya kekaburan norma dalam penelitian ini berkaitan dengan tidak jelasnya aturan mengenai degradasi akta Notaris menjadi akta di bawah tangan.

Berdasarkan atas penggunaan bahan hukum primer bahan hukum sekunder dan bahan hukum tertier dalam penelitian hukum normatif, maka dapat diuraikan sebagai berikut dibawah ini:

1. Bahan Hukum Primer.

Bahan hukum primer yaitu bahan-bahan hukum yang sifatnya mengikat. Bahan hukum primer dalam penelitian ini antara lain, Kitab Undang-Undang Hukum Perdata, Undang-Undang Republik Indonesia Nomor 2 Tahun 2014 Tentang Perubahan Atas Undang-Undang Nomor 30 Tahun 2004 Tentang Jabatan Notaris, Lembaran Negara Republik Indonesia Tahun 2014 Nomor 293, Tambahan Lembaran Negara Republik Indonesia Nomor 5602, dan Kode Etik Notaris.

2. Bahan Hukum Sekunder.

Bahan hukum sekunder dapat diperoleh dari hasil penelitian hukum, hasil ilmiah dari kalangan hukum. Bahan hukum sekunder dalam penelitian ini antara lain buku-buku mengenai hukum perdata, hukum perjanjian, akta, jabatan Notaris dan buku-buku yang terkait dalam pembahasan penelitian ini.

3. Bahan Hukum Tertier

Bahan hukum tertier merupakan bahan yang memberikan petunjuk maupun penjelasan terhadap bahan hukum primer dan sekunder. Bahan hukum tertier dapat berupa kamus hukum, ensiklopedia dan lain-lain.

Mengenai teknik yang diterapkan dalam pengolahan bahan hukum yang diperlukan dalam penelitian ini adalah melalui teknik telaah kepustakaan (study document). Telaah kepustakaan dilakukan dengan sistem kartu (card system) yakni dengan cara mencatat dan memahami isi dari masing-masing informasi yang diperoleh dari bahan hukum primer, bahan hukum sekunder maupun bahan hukum tertier.

Teknik analisis bahan hukum yang dipergunakan dalam penelitian ini adalah teknik deskriptif, teknik interpretasi (penafsiran), teknik evaluasi dan teknik argumentasi. Teknik deskriptif merupakan teknik dasar yang digunakan untuk menganalisis suatu permasalahan yang harus digunakan dalam suatu penelitian. Deskriptif berarti bahwa menguraikan suatu keadaan posisi dari proposisi-proposisi hukum atau non hukum.

\section{Hasil Dan Pembahasan}

Tugas dari seseorang Notaris ialah untuk menuangkan secara tertulis dan autentik hubungan-hubungan hukum para penghadap yang menggunakan jasa Notaris

${ }^{10}$ Sari, A. A. I. P., \& Darmawan, N. K. S. (2015). Keabsahan Perjanjian Nominee Kepemilikan Saham Dalam Pendirian Perseroan Terbatas. Kertha Semaya. 
tersebut dalam kepentingan mereka akan Akta Notaris yang mempunyai fungsi sebagai syarat formil suatu hubungan hukum tertentu dan dapat juga berfungsi sebagai suatu alat bukti dalam persidangan yang memiliki kekuatan pembuktian sempurna dalam artian akta tersebut tidak perlu lagi memerlukan alat bukti lainnya dan cukup hanya mengacu kepada apa yang tertuang dalam isi akta autentik tersebut. Dalam menjalankan tugas dan jabatannya maka Notaris dapat saja melakukan kelalaian dalam pembuatan akta autentik yang tentunya dapat mengakibatkan akta Notaris tersebut menjadi akta yang tidak autentik lagi, sehingga dapat menimbulkan kerugian bagi para penghadap serta para pihak yang terkait dengan akta Notaris tersebut dan tentunya bagi para penghadap yang menggunakan jasanya. ${ }^{11}$

Untuk memberikan suatu perlindungan kepada masyarakat dari rasa takut terhadap gangguan tindak pidana atau kejahatan, maka dari itu sangat diperlukan suatu upayaupaya penanggulangan dari pemerintah dan aparat penegak hukum. ${ }^{12}$ Perjanjian dapat diartikan sebagai suatu hubungan hukum antara 2 (dua) pihak atau lebih yang berdasarkan adanya kata sepakat yang menimbulkan suatu akibat hukum. Perjanjian dapat diartikan suatu peristiwa dimana seorang berjanji kepada seorang lain atau dimana dua orang itu saling berjanji untuk melaksanakan suatu hal. Akibat yang timbul dari perjanjian yang dilakukan oleh para pihak ialah suatu hubungan hukum berdasarkan mana pihak yang satu berhak menuntut sesuatu hal dari pihak yang lain dan pihak yang lain berkewajiban untuk memenuhi tuntutan. Berdasarkan ketentuan Pasal 1313 KUH Perdata menetukan bahwa: "perjanjian adalah suatu perbuatan dengan mana satu orang atau lebih mengikatkan dirinya terhadap satu orang lain atau lebih. Bentuk perjanjian dapat berupa tertulis dan lisan". Suatu perjanjian dapat dikatakan sah apabila memenuhi ketentuan dalam Pasal 1320 KUH Perdata yaitu, sepakat, kecakapan bertindak, obyek tertentu dan perjanjian tersebut harus memenuhi kausa yang halal. Syarat kesepakatan dan kecakapan bertindak merupakan syarat subyektif sedangkan syarat obyek tertentu dan kausa yang halal adalah syarat obyektif. Akibat tidak dipenuhinya syarat subyektif adalah perjanjian yang dibuat oleh para pihak dapat dibatalkan, yaitu perjanjian tersebut tidak akan berlaku lagi sejak permohonan pembatalan tersebut dikabulkan oleh Pengadilan. Apabila perjanjian tersebut tidak memenuhi syarat obyektif maka, perjanjian tersebut batal demi hukum dan perjanjian dianggap tidak pernah ada.

Suatu perjanjian dapat digunakan menjadi suatu alat bukti di kemudian hari apabila pelaksanaan perjanjian yang dilakukan oleh para pihak tersebut bermasalah. Setiap orang yang mendalilkan bahwa ia mempunyai suatu hak atau guna meneguhkan haknya sendiri ataupun membantah seuatu hak orang lain, menunjuk suatu peristiwa diwajibkan membuktikan adanya hak atau peristiwa tersebut, demikian ketentuan Pasal 1865 KUH Perdata. Ada 2 (dua) macam bentuk akta yaitu akta autentik dan akta di bawah tangan. Akta autentik menurut Pasal 1868 Kitab Undang-Undang Hukum Perdata adalah akta yang dibuat dalam bentuk yang sesuai dengan ketentuan undangundang, dihadapan pejabat yang berwenang, ditempat akta tersebut dibuat. Ketentuan dalam pasal tersebut merupakan syarat yang harus dipenuhi untuk membuat akta

11 Winardy, A. (2012). Akibat Hukum Dan Tanggung Jawab Notaris Atas Akta Notaris Yang Memuat Data Yang Keliru Akibat Kelalaian Notaris (Doctoral Dissertation, Universitas Airlangga).

${ }^{12}$ Hendrawan, I. G. A. D. (2015) Penegakan Hukum Pidana Dalam Upaya Penanggulangan Gelandangan Dan Pengemis Di Kota Denpasar. 
autentik. Selanjutnya dalam Pasal 1870 KUH Perdata menjelaskan bahwa akta autentik memberikan suatu bukti yang sah sempurna tentang apa yang dimuat di dalamnya bagi para pihak beserta ahli waris atau orang-orang yang mendapat hak dari mereka. Ketentuan mengenai kewenangan pejabat dalam membuat akta otentik berkaitan dengan wilayah jabatan dan kedudukannya. Sehingga dimana akta otentik tersebut dibuat sangat berkaitan erat dengan wilayah jabatan serta kedudukan pejabat tersebut berada.

Akta Notaris yang dibuat di hadapan Notaris merupakan suatu perjanjian bagi kedua belah pihak yang menyangkut hak dan kewajiban bagi para pihak yang membuatnya, sehingga diperlukan syarat-syarat sahnya perjanjian. Akta Notaris merupakan alat bukti yang sempurna yang berarti kebenarannya dari hal-hal yang tertulis dalam akta tersebut harus diakui oleh semua pihak, yaitu akta Notaris tersebut haruslah dianggap benar, selama kebenarannya itu tidak dapat membuktikan sebaliknya. ${ }^{13}$ Suatu akta autentik merupakan alat bukti yang mempunyai kekuatan pembuktian yang sempurna, pembuatan akta otentik dilakukan oleh dan atau di hadapan pejabat dengan dihadiri oleh para saksi dan para pihak. Ada dua macam akta autentik yaitu akta pejabat atau (ambtelijk akta) dan akta para pihak yang dibuat dihadapan pejabat atau (relaas akta). Akta pejabat merupakan akta yang dibuat oleh pejabat dan tanggung jawab atas akta tersebut merupakan tanggung jawab pejabat yang membuat bukan para pihak yang berada dalam akta tersebut. Akta para pihak merupakan akta yang dibuat oleh para pihak dan dibuat dihadapan oleh pejabat yang berwenang akan tetapi tanggung jawab apabila terjadi permasalahan, ada dalam para pihak yang membuatnya. Dalam hal ini pejabat tidak dapat dituntut atas apa yang dituangkan dalam akta tersebut. apabila keterangan yang diberikan oleh para pihak kepada pejabat untuk dituangkan di dalam perjanjian tersebut merupakan palsu maka akta tersebut tetap sah dan bukan akta palsu tetapi keterangan yang tertuang dalam akta tersebut palsu. Pejabat pembuat akta dalam hal ini dikenal sebagai Notaris. Berdasarkan ketentuan Pasal 1 angka 1 UUJN menentukan bahwa: "Notaris adalah pejabat umum yang berwenang untuk membuat akta autentik dan memiliki kewenangan lainnya sebagaimana dimaksud dalam Undang-Undang ini atau berdasarkan undang-undang lainnya". Mengenai syarat suatu akta memiliki kekuatan sebagai akta otentik diatur sebagaimana yang ditentukan berdaarkan ketentuan Pasal 1868 KUHPer jo Pasal 38 UUJN antara lain yaitu:

1) Harus sesuai dengan bentuk yang diatur dalam undang-undang Syarat untuk membuat akta autentik dibuat sesuai dengan Pasal 1868 KUHPer yaitu harus sesuai dengan bentuk yang diatur dalam undang-undang. Pasal 38 ayat (2) UUJN menyatakan bahwa awal akta atau kepala akta memuat, judul akta, nomor akta, jam, hari, tanggal, bulan, dan tahun, dan nama lengkap dan tempat kedudukan Notaris

Selanjutnya dalam ketentuan Pasal 38 ayat (3) UUJN menentukan bahwa badan akta haruslah memuat:

${ }^{13}$ Ehwan, Z. (2011). Otentisitas Akta Notaris Sebagai Alat Bukti Yang Sempurna Terhadap Degradasi Kekuatan Pembuktian Dan Kebatalan Akta Otentik (Analisis Terhadap Putusan Ma Ri No. 3148 K/Pdt/1988) (Doctoral Dissertation, Diponegoro University). 
1) nama lengkap, tempat dan tanggal lahir, kewarganegaraan, pekerjaan, jabatan, kedudukan, tempat tinggal para penghadap dan/atau orang yang mereka wakili

2) keterangan mengenai kedudukan bertindak penghadap

3) isi akta yang merupakan kehendak dan keinginan dari pihak yang berkepentingan, dan

4) nama lengkap, tempat dan tanggal lahir, serta pekerjaan, jabatan, kedudukan, dan tempat tinggal dari tiap-tiap saksi pengenal

Lebih lanjut diatur dalam ketentuan Pasal 38 ayat (4) UUJN menentukan bahwa penutup akta memuat:

1) uraian tentang pembacaan akta sebagaimana dimaksud dalam Pasal 16 ayat (1) huruf I atau Pasal 16 ayat (7)

2) uraian tentang penandatanganan dan tempat penandatanganan atau penerjemahan akta apabila ada

3) nama lengkap, tempat dan tanggal lahir, pekerjaan, jabatan, kedudukan, dan tempat tinggal dari tiap-tiap saksi akta, dan

Berdasarkan penjelasan padapasal tersebut maka dapat disimpulkan bahwa suatu akta dapat dikategorikan sebagai akta yang autentik bilamana dalam pembuatan akta tersebut sesuai dengan prosedur yang sudah ditentukan berdasarkan ketentuan Pasal 38 UUJN, suatu akta Notaris dapat dikatakan memenuhi syarat sebagai akta yang autentik apabila akta Notaris tersebut sudah sesuai dengan prosedur-prosedur dan tata cara yang memang sudah ditentukan berdasarkan ketentuan Pasal 39 UUJN sampai dengan Pasal 53 UUJN, maka akta Notaris tersebut dapat dikatakan sebagai suatu akta yang autentik yang mempunyai kekuatan pembuktian yang sempurna bagi para pihak yang membuatnya.

Degradasi diartikan sebagai penurunan tentang pangkat, mutu, moral, kemerosotan, kemunduran, atau dapat juga menempatkan ditingkat yang lebih rendah. Dalam kaitannya dengan akta Notaris, istilah terdegradasi terjadi manakala akta Notaris sebagai akta autentik yang memiliki kekuatan bukti sempurna dan mengikat, serta telah mencukupi batas minimal alat bukti yang sah tanpa lagi diperlukan alat bukti lain dalam sengketa hukum perdata mengalami kemunduran, kemerosotan, atau penurunan mutu dalam arti posisinya lebih rendah dalam kekuatan sebagai alat bukti lengkap dan sempurna menjadi permulaan pembuktian seperti akta di bawah tangan dan memiliki cacat hukum yang menyebabkan pembatalan atau ketidakabsahannya akta Notaris tersebut. ${ }^{14}$ Akta Notaris dapat terdegradasi otentitasnya dari akta autentik menjadi akta di bawah tangan atau akta menjadi batal demi hukum dan dapat digunakan dasar untuk menggugat ganti kerugian. ${ }^{15}$

Pembuatan akta yang dilakukan oleh seorang Notaris, tidak secara otomatis dapat disebut sebagai akta yang autentik. Hal itu disebabkan oleh ketentuan perundangundangan yang menyebutkan bahwa terhadap hal-hal formil tertentu, akta autentik

${ }^{14}$ Andre, P. R. (2015). Tanggung Jawab Notaris Terhadap Akta Yang Terdegradasi Nilai Pembuktiannya Menjadi Akta Dibawah Tangan (Doctoral Dissertation, Universitas Andalas).

${ }^{15}$ Zulkarnain, F. A. (2013). Tanggung Jawab Notaris Terhadap Akta Yang Dibuat Karena Ancaman Dan Pemalsuan (Analisis Putusan Mahkamah Agung No. 688 K/Pid/2006) (Doctoral Dissertation, Universitas Airlangga). 
tersebut akan turun kekuatannya menjadi akta dibawah tangan. Kekuatan pembuktian akta autentik merupakan suatu keadaan menilai akta autentik sebagai suatu alat bukti. Dalam hal ini ada 3 (tiga) aspek yang harus diperhatikan ketika akta dibuat, aspekaspek ini berkaitan dengan nilai pembuktian, antara lainn yaitu: ${ }^{16}$

1) Lahiriah (uitwendige bewijskracht)

Kemampuan lahiriah dari akta Notaris tersebut merupakan kemampuan akta itu sendiri untuk dapat membuktikan keabsahannya sebagai akta yang autentik (acta publica probant seseipsa). Maka jika dilihat dari tahap pembuatannya sebagai akta yang autentik maka akta Notaris tersebut tetaplah menjadii akta yang autentik, sampai adanya gugatan dari pihak lain yang sudah mempunyai kekuatan hukum yang tetap. Dan mengenai beban pembuktian di persidangan maka pihak yang menyangkalnya harus dapat menyajikan bukti-bukti yang sah bahwa akta Notaris tersebut memang cacat dari pada saat pembuatannya. Kekuatan akta Notaris dari aspek lahiriah maksudnya yaitu akta Notaris tersebut haruslah dianggap sebagai akta yang sah sebagaimana adanya, maka dari itu tidak diperlukan lagi alat bukti lainnya untuk menunjang keabsahan dari akta Notaris tersebut, terkait dengan pembuktian maka pihak yang menyangkal keotentikan akta Notaris dari aspek lahiriah tersebut diwjibkan untuk membuktikan penyangkalan akta Notaris tersebut. Pembuktian tersebut dilakukan pada saat adanya gugatan di pengadilan.

2) Formil (formele bewijskracht)

Mengenai aspek formil suatu akta Notaris, maka akta Notaris tersebut haruslah memberikan kepastian mengenai suatu kejadian maupun perbuatan hukum yang dilakukan oleh para pihak serta untuk membuktikan secara formil mengenai kepastian hari, tanggal, bulan, tahun, pukul (waktu) menghadap dan para pihak yang menghadap, paraf dan tanda tangan para penghadap, saksi dan Notaris. Hal ini juga untuk membuktikan apa yang dilihat, disaksikan, didengar oleh Notaris (pada akta pejabat/berita acara) dan mencatatkan keterangan atau pernyataan para pihak/penghadap (pada akta pihak). Penyangkalan terhadap aspek formil suatu akta Notaris, maka para pihak yang menyangkalnya diwajibkan untuk membuktikan penyangkalannya tersebut dalam suatu persidangan di pengadilan, dan mengenai beban pembuktian diserahkan sepenuhnya pada pihak yang menyangkal tersebut.

3) Materiil (materiele bewijskracht)

Mengenai aspek metelil suatu akta Notaris yaitu tentang keabsahaan materi yang termuat dalam isi akta Notaris tersebut haruslah dianggap sah sapai dapat diuktikan sebaliknya (tegenbewijs). Mengenai materi yang terbuat dalam akta Notaris merupakan pernyataan dan kehendak dari para penghadap yang datang kepada Notaris untuk dibuatkan suatu akta yang autentik. Penyangkalan terhadap aspek materil akta Notaris dapat dilakukan suatu gugatan ke pengadilan dengan pebuktian terbalik yang dilakukan oleh pihak yang menyangkalnya.

Ketiga aspek tersebut diatas merupakan suatu syarat dari kesempurnaan dari akta Notaris sebagai suatu akta yang autentik dan siapapun juga terikat oleh keberadaan akta Notaris tersebut. Jika dapat dibuktikan dalam suatu persidangan pengadilan

${ }^{16}$ Habib Adjie. (2008). Hukum Notaris Indonesia (Tafsir Tematik Terhadap UU No.30 Tahun 2004 Tentang Jabatan Notaris). Bandung: PT. Refika Aditama, h. 26 
bahwa ada salah satu aspek tersebut tidak benar, maka akta Notaris tersebut hanya mempunyai kekuatan pembuktian sebagai suatu akta dibawah tangan saja. Dengan kata lain bahwa akta Notaris tersebut dapat didegradasikan kekuatan pembuktiannya menjadi akta yang mempunyai kekuatan pembuktian sebagai akta dibawah tangan saja.

Berdasarkan ketentuan Pasal 40 UUJN menentukan bahwa: "Notaris diwajibkan untuk membacakan akta dihadapan penghadap dengan dihadiri oleh paling sedikit dua orang saksi, atau empat orang saksi bagi pembuatan akta wasiat dibawah tangan". Kemudian lebih lanjut dalam ketentuan Pasal 16 ayat (9) UUJN menentukan bahwa: "atas tidak dibacakannya akta dengan jumlah saksi yang telah ditentukan tersebut dapat menyebabkan akta yang dibuat notaris menjadi akta dibawah tangan". Akan tetapi di dalam undang-undang ditemukan pengecualian terhadap para pihak berkehendak agar Notaris tidak perlu membacakan isi akta tersebut dikarenakan para pihak telah memahami dan mengetahui isinya. Maka para pihak diwajibkan untuk memberikan paraf pada setiap halamannya oleh para pihak, saksi dan Notaris. Ditambahkan pula bahwa kehendak tersebut haruslah ditulis pada penutup akta. Namun jika ketentuan ini baik sebagian maupun keseluruhannya tidak di lakukan oleh Notaris yang membuat akta itu, maka kekuatan pembuktian akta Notaris tersebut menjadi dibawah tangan, berdasarkan ketentuan pada pasal tersebut maka pelanggaran terhadap ketentuan pasal tersebut dapat membuat akat Notaris terdegradasi menjadi akta dibawah tangan saja. Selanjutnya terhadap Notaris yang melakukan penggantian, penambahan, pencoretan, penyisipan, penghapusan dan tulis tindih terhadap isi akta setelah dilakukan penandatangan, maka akta tersebut menjadi akta dibawah tangan. Jika dilakukan sebelum akta di tanda tangani namun tidak memperhatikan persyratannya, maka akta tersebut menjadi akta dibawah tangan pula. Persyaratan yang dimaksud adalah bahwa terhadap perbaikan atas kekeliruan maka harus dilakukan dibuat pada sisi kiri akta. Selanjutnya berdasarkan ketentuan Pasal 52 UUJN menentukan bahwa:

Notaris tidak diperkenankan untuk membuat akta bagi diri sendiri, suami/istri, atau orang lain yang mempunyai hubugan kekeluargaan dengan notaris baik karena perkawinan maupun hubungan darah dalam garis keturunan kebawah dan/atau keatas tanpa pembatasan derajad, serta dalam garis kesamping sampai derajad ketiga, serta menjadi pihak untuk diri sendiri maupun dalam suatu kedudukan ataupun dengan perantara kuasa. Pelanggaran ketentuan ini juga berakibat turunnya akta autentik menjadi akta dibawah tangan.

Berdasarkan penjelasan diatas sudah disebutkan mengenai hal-hal yang berlaku khusus terhadap hal-hal yang dapat menurunkan derajad suatu akta otentik. Selanjutnya berdasarkan ketentuan Pasal 1869 KUH Perdata menentukan bahwa akta tidak dapat disebut sebagai akta yang autentik jika:

1) Pejabat umum tidak berwenang melakukan.

Untuk mengetahui hal apa saja yang Notaris tidak berwenang melakukannya, perlu merujuk pada kewenangan Notaris yang diatur dalam Pasal 15 UUJN yang menentukan bahwa:

Notaris berwenang untuk membuat akta autentik mengenai semua perbuatan, perjanjian dan penetapan yang diharuskan oleh peraturan perundang-undangan dan/atau dikehendaki oleh yang berkepentingan untuk dinyatakan dalam akta autentik, menjamin kepastian tanggal 
pembuatan akta, menyimpan akta memberikan grosse, salinan dan kutipan akta, semuanya itu sepanjang pembuatan akta itu tidak juga ditugaskan atau dikecualikan kepada pejabat lain atau orang lain yang ditetapkan oleh undang-undang.

Selain itu Notaris juga berwenang untuk: mengesahkan tanda tangan dan menetapkan kepastian tanggal surat dibawah tangan dengan mendaftar dibuku khusus; membukukan surat dibawah tangan dengan mendaftar dibuku khusus; membuat kopi dari asli surat dibawah tangan berupa salinan yang memuat uraian sebagaimana ditulis dalam surat yang bersangkutan;melakukan pengesahan kecocokan fotokopi dengan yang aslinya; memberikan penyuluhan hukum yang berkaitan dengan pembuatan akta; membuat akta yang berkaitan dengan pertanahan; membuat akta risalah lelang. Dengan uraian diatas maka, kewenangan yang dilakukan notaris diluar ketentuan perundang-undangan adalah tindakan yang diluar kewenangan dan atas produk yang dihasilkannya mempunyai kekuatan pembuktian dibawah tangan.

2) Pejabat umum tidak cakap dalam tindakannya.

Persyaratan kecakapan adalah syarat yang melekat pada diri subjektif pejabat itu sendiri. Bukan pada jabatannya. Ketidakcakapan disini dapat berarti bahwa pejabat dirinya belum dewasa, pejabat umum yang ditaruh dibawah pengampuan, perempuan yang telah kawin dalam hal ditetapkan pengadilan.

3) Terdapat kecacatan dalam bentuk akta autentik tersebut.

Berdasarkan Pasal 84 UUJN dinyatakan bahwa tindakan pelanggaran yang dilakukan oleh Notaris terhadap ketentuan sebagaimana dimaksud dalam Pasal 16 ayat (1) huruf i, Pasal 16 ayat (1) huruf k, Pasal 41, Pasal 44, Pasal 48, Pasal 49, Pasal 50, Pasal 51, atau Pasal 52 yang mengakibatkan suatu akta hanya mempunyai kekuatan pembuktian sebagai akta di bawah tangan atau suatu akta menjadi batal demi hukum dapat menjadi alasan bagi pihak yang menderita kerugian untuk menuntut penggantian biaya, ganti rugi, dan bunga kepada Notaris.

Berdasarkan penjelasan tersebut maka dapat disimpulkan bahwa akta yang dibuat oleh dan di hadapan Notaris dapat terdegradasi menjadi akta dibawah tangan bilamana pada saat proses pembuatan terjadinya akta autentik tersebut tidak memenuhi formalitas formalitas yang memang sudah ditentukan dalam UJJN, maka akta Notaris tersebut dapat kehilangan nilai pembuktian yang sempurna dan hanya menjadi akta di bawah tangan saja, dan apabila dapat dibuktikan dalam sidang pengadilan bahwa akta tersebut mengandung cacat hukum maka akta Notaris tersebut dapat dibatalkan berdasarkan keputusan pengadilan yang sudah mempunyai kekeuatan hukum yang tetap.

\section{Kesimpulan}

Berdasarkan pembahasan permasalahan yang telah diuraikan diatas, maka dapat disimpulkan bahwa akibat hukum dari akta Notaris yang terdegradasi adalah tidak dapat digunakan lagi sebagai alat bukti yang sempurna karena akta autentik merupakan alat bukti yang sempurna atau memiliki kekuatan pembuktian yang sempurna. Berdasarkan ketentuan Pasal 1868 KUH Perdata haruslah dipenuhi syarat akta autentik serta akta otentik haruslah dibuat sesuai dengan format yang sudah 
ditentukan berdasarkan ketentuan Pasal 38 UUJN dan akta Notaris dapat terdegradasi menjadi akta di bawah tangan apabila melanggar ketentuan Pasal 1868 KUH Perdata dan jo UUJN, selanjutnya mengenai rekomendasi yang dapat diberikan terhadap pembahasan ini yaitu disarankan agar dalam pembuatan akta Notaris disesuaikan dengan peraturan yang ada dan cermat dalam pembuatan akta Notaris agar akta tersebut memiliki kekuatan pembuktian yang sempurna dan demi memberikan kepastian hukum yang melindungi kepentingan para pihak.

\section{Daftar Pustaka}

Buku

Adjie, Habib. (2008). Hukum Notaris Indonesia (Tafsir Tematik Terhadap UU No.30 Tahun 2004 Tentang Jabatan Notaris). Bandung: PT. Refika Aditama.

Mertokusumo, Sudikno. (1999). Mengenal Hukum Suatu Pengantar. Yogyakarta: Liberty.

Notodisoerjo, Soegondo. (1993). Hukum Notariat di Indonesia (Suatu Penjelasan). Jakarta: Raja Grafindo Persada.

Notohamidjojo. (2011). Soal-Soal Pokok Filsafat Hukum. Salatiga: PT. Griya Media.

Pontier, J.A. (2008). Penemuan Hukum. Bandung: Jendela Mas Pustaka.

\section{Jurnal}

Hendrawan, I. G. A. D. (2015). Penegakan Hukum Pidana Dalam Upaya Penanggulangan Gelandangan Dan Pengemis Di Kota Denpasar. Kumpulan Jurnal Mahasiswa Fakultas Hukum.

Krisno, A. D. J., Dharmawan, N. K. S., \& Darmadi, A. S. W. (2015). Akibat Hukum Yang Ditimbulkan Dari Wanprestasi Dalam Perjanjian Autentik SewaMenyewa Tanah. Kumpulan Jurnal Mahasiswa Fakultas Hukum.

Nitasari, K. R. (2018). Akibat Hukum Dari Perjanjian Kredit Bank Yang Tidak Dilegalisasi Oleh Notaris. Kumpulan Jurnal Mahasiswa Fakultas Hukum.

Prayojana, D. A., Murni, R. R., \& Dharmawan, N. K. S. (2018). Pelaksanaan Penyelesaian Pelanggaran Kode Etik Notaris Tentang Pemasangan Papan Nama Notaris Di Kota Denpasar. Acta Comitas.

Sari, A. A. I. P., \& Darmawan, N. K. S. (2015). Keabsahan Perjanjian Nominee Kepemilikan Saham Dalam Pendirian Perseroan Terbatas. Kertha Semaya.

Setiabudhi, I. K. R., \& Swardhana, G. M. (2017). Sanksi Hukum Terhadap Notaris Yang Melanggar Kewajiban Dan Larangan Undang-Undang Jabatan Notaris. Acta Comitas.

\section{$\underline{\text { Desertasi }}$}

Andre, P. R. (2015). Tanggung Jawab Notaris Terhadap Akta Yang Terdegradasi Nilai Pembuktiannya Menjadi Akta Dibawah Tangan (Doctoral Dissertation, Universitas Andalas).

Ehwan, Z. (2011). Otentisitas Akta Notaris Sebagai Alat Bukti Yang Sempurna Terhadap Degradasi Kekuatan Pembuktian Dan Kebatalan Akta Otentik (Analisis Terhadap Putusan Ma Ri No. 3148 K/Pdt/1988) (Doctoral Dissertation, Diponegoro University).

Winardy, A. (2012). Akibat Hukum Dan Tanggung Jawab Notaris Atas Akta Notaris Yang Memuat Data Yang Keliru Akibat Kelalaian Notaris (Doctoral Dissertation, Universitas Airlangga). 
Zulkarnain, F. A. (2013). Tanggung Jawab Notaris Terhadap Akta Yang Dibuat Karena Ancaman Dan Pemalsuan (Analisis Putusan Mahkamah Agung No. 688 K/Pid/2006) (Doctoral Dissertation, Universitas Airlangga).

\section{Peraturan Perundang-undangan}

Kitab Undang-Undang Hukum Perdata.

Undang-Undang Republik Indonesia Nomor 2 Tahun 2014 Tentang Perubahan Atas Undang-Undang Nomor 30 Tahun 2004 Tentang Jabatan Notaris, Lembaran Negara Republik Indonesia Tahun 2014 Nomor 293, Tambahan Lembaran Negara Republik Indonesia Nomor 5602.

\section{Website}

Prinsip Kehati-hatian Notaris Dalam Membuat Akta Autentik Autentik from, https://ojs.unud.ac.id/index.php/ActaComitas/article/view/39328/23810, (Diakses 13 Juni 2018). 